\title{
The Greek shield as a metal artifact and its reflection in the story of the Croesus' gifts in Thebes
}

\author{
A. Yu. Mozhajsky, Associate Professor, Department of Ancient History and Byzantium ${ }^{1}$, Senior Researcher ${ }^{2}$, \\ e-mail:amozhayskiy@hse.ru \\ V. K. Pichugina, Leading Researcher², e-mail: pichugina_v@mail.ru \\ 1 Institute for Oriental and Classical Studies, National Research University Higher School of Economics, Russia, Moscow. \\ 2 Institute for Strategy of Education Development of the Russian Academy of Education, Russia, Moscow.
}

\begin{abstract}
The article is devoted to the study of archaeological evidences and literary tradition regarding ancient Greek shields as metal artifacts or as the artifacts made by the use of metal. Presented is an attempt at interpreting the names

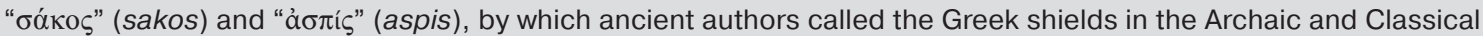
Periods. New data on the dating of some artefacts let assume that a number of shields, the production technology of which goes back to the Late Bronze Age or made later (in the Geometric or Archaic Periods) may have been displayed in sanctuaries under the influence of the artifacts from the Late Bronze Age. The authors propose a version according to which Herodotus, describing the Croesus' gifts in Thebes, uses the word " $\sigma$ áко", thereby emphasizing the uncommonness of the golden shield, its heroic antiquity and the reliability of the Amphiaraus' shield. Archaeological parallels and the words " $\varphi \alpha \varepsilon v a ̀ v ~[\alpha \dot{\sigma} \sigma \pi] i ́ \delta \alpha$ " from an inscription found in Thebes suggest that it was a round shield. This artifact had not only a religious, but also a historical and educational function, being an article that bounds up the Thebans with their heroic past.
\end{abstract}

Key words: shield, bronze, gold, sakos, aspis, Thebes, Amphiaraus, Croesus, Herodotus, Apollo Ismenios, Delphi. DOI: $10.17580 / \mathrm{nfm} .2020 .02 .10$

\section{Introduction}

$\mathrm{T}$ he article presents an attempt to combine in the research both archaeological evidences and written sources relating to the ancient Greek shield. We will indicate the differences between the names "бóкољ" and " $\dot{\alpha} \sigma \pi i \varsigma$ ", mentioned in the epic poetry; reveal the main properties and construction of the bronze-plated hoplite shield and some preceding types, and trace the impact of the shield phenomenon on the Theban mytho-history by the example of the Croesus' gifts to Amphiaraus, mentioned by Herodotus (Hdt. 1.52). There is a considerable historiography on the first two issues, so our excursus is selective and collective in character and takes into account modern achievements. We hope that it will be interesting to the readers of the journal to address themselves to the history of metallurgy and the main characteristics of the bronze-plated shields.

As regards the production technology and performance attributes based on hypothetical reconstructions of the shields, which are mentioned in Homeric poems, we refer the readers to the following book: Paipetis $S$. A. The Unknown Technology in Homer. Dordrecht, 2010. $210 \mathrm{p}$. (for shields and other protective armament see subsection: Part 4).

As for Thebes, we offer a study which let expand an understanding of difficult questions about comparison of

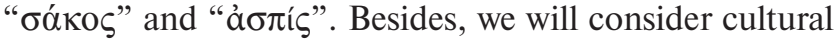
and historical as well as historical and educational consti- tuents of the shield as an artifact that has been in Herodotus' time in Thebes.

\section{Literary tradition and archaeology}

Before presenting the types of the shields known from archaeological data, let us pay attention to the terms that denote shields in the epic tradition (Homeric poems, works of Hesiod and Aeschylus). There is an idea regarding the Iliad and Odyssey that they were created approximately in the middle or last part of the VIII century BC. However, the historiographical trend is such that a number of researchers propose to date these works to the time around $700 \mathrm{BC}$ or even later, up to $678 \mathrm{BC}$ as terminus post quem and around $630 \mathrm{BC}$ as terminus ante quem [26; 16, p. 131; 149-152]. As regards the works of Hesiod, the near dating is assumed: around $700 \mathrm{BC}$ or a little later, since the date can be attributed to the Lelantine war $[18 ; 16$, p. 152]. The creation time of Aeschylus' Seven Against Thebes refers to the period from 475 to $470 \mathrm{BC}[27$, p. 81 ; 10 , p. $233 ; 1$, p. $307-308]$. In that way, the period from around 700 to around $470 \mathrm{BC}$, or the time from the Archaic to the Early Classical Period is considered in relation to the terms that denote the shield in literary sources. Already in Homeric poems, shields are designated by

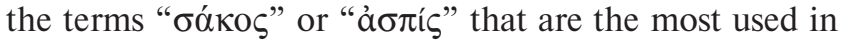
epic poetry. In modern research, these terms are usually considered as distant reflection of once different types

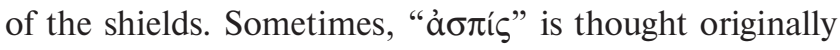




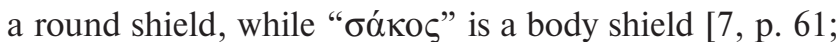
5, p. 178-179). However, as noted by Bershadsky, Achil-

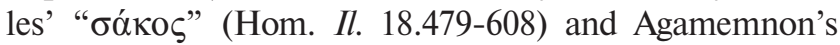
"ảotíc" (Hom. Il. 11.32-40), are made exclusively of metal, decorated and have more common features than

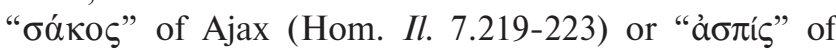
Sarpedon (Hom. Il. 12.294-297), which are both made of oxhide and bronze [2, p. 3]. Having fulfilled quantitative and contextual usage analysis of the terms under discussion, Bershadsky notes that in the Iliad the hero is never

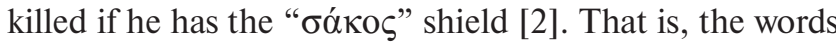
denoting shields in Homeric poems do not reflect the type of a shield, but the degree of the hero protectability. In such a way, there is confirmed the Grethlein's assumption that the Iliad contains recollections of these shields with-

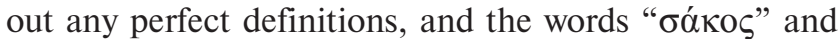

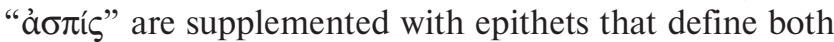
of them as a small round shield and as a long shield; if the idea of a long shield is not interpreted as a fantastic expression of the hero's strength, it corresponds to the image of Mycenaean long shields [6, p. 169].

This brings up the question: If a long shield corresponds to any of the Late Bronze Age periods, then what time can a small round shield belong to?

As early as in 1967, Snodgrass has noted that a small, circular shield is the commonest variety for the period $1250-1150 \mathrm{BC}$. However, regarding the material of which the shields were made, the researcher notes that "these shields must all be largely of hide, like their predecessors, but they may have had a metal accessory in the shape of one or more large bronze discs, about six inches across, with a domed centre and sometimes a protruding spike" and further "a twelfth-century grave at Mouliana in Crete produced the earliest specimens, but more impressive evidence comes from Cyprus in a slightly later period (11001050 BC - A. Mozhajsky, V. Pichugina), a find which also shows that a metal border could be attached to such a shield" [23, p. 32-33]. In the following period of the the Early Iron Age (right up to VIII century BC) finds of bosses from the shields "occur both in Greece and in Cyprus". Systematizing the finds of this time, Snodgrass marks that now such bosses "almost always found singly, suggesting a smaller, probably round shield, the basic material of which must be hide" [23, p. 44]. These shields probably have had a central handle, using which, if needed, it was possible to put forward the shield to the full length of an arm, as did Deiphobus in one of the episodes of the Iliad: $\Delta$ †i

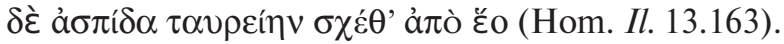

However, since when does the archaeological data provide the shield-modeled, fully bronze objects or bronze-plated shields? Let us start with the fact that the images of small round shields from the Late Bronze Age (LH IIIC period, 1200/1190-1075/50 BC) correspond in proportions to the European samples "of Urnfield groups (broadly defined) in Italy, the Balkans, and central Europe": $50-60 \mathrm{~cm}$ in diameter, based on the proportion comparison between shields and people who hold them
[25, p. $130-136 ; 12$, p. 284-285]. The researchers have noticed that in the last decades before the destruction of the palaces, some of Mycenaean centres may have been in contact with Urnfield groups, and later "many metal objects were made in Greece that had features that looked like and functioned in similar fashions as objects made in the Urnfield tradition, but many of these same objects also had features derived from Aegean smithing traditions" [12, p. 281; Cf. 11]. In this respect, we believe that if the dating of the small round shield No. 3642 at the Archaeological Museum in Delphi (Delphi Shield 1 by Molloy's classification), that Molloy suggests is correct, then here is a possible prototype of the LH IIIC period for the

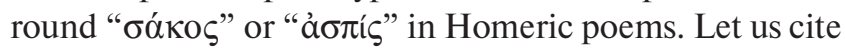
a description of this shield in Molloy [12, p. 288]: "The shield today is fragmentary, so its original diameter cannot be defined. It features a central boss that is $13.0 \mathrm{~cm}$ in diameter and $4.0 \mathrm{~cm}$ high from the front. The shield, as it survives, weighs $1,117 \mathrm{~g}$, suggesting the original complete item weighed a little over $2,000 \mathrm{~g}$, which is consistent with the comparatively heavy (by European standards) Group Plzeň shields, an admittedly broad group consisting of three shields, two provenanced to Denmark and one to the Czech Republic. A handle was originally attached as indicated by three rivets and one rivet hole measuring ca. $5.8-7.0 \mathrm{~mm}$ in diameter. The length of the rivets suggests the handle was ca. $3.0-4.0 \mathrm{~mm}$ thick where it attached to the body of the shield, and the deformation on the interior end of the surviving rivets indicates that the handle was forcibly removed. The simple (non-stepped) domed central boss is consistent with Lommelev-Nyitura-type or Herzsprung designs... It is surrounded by three concentric embossed rings, each with a $\mathrm{V}$-notch pointing toward the boss and aligned with the axis of the handle. The notches are then surrounded by a row of miniature bosses, a further embossed ring with no apparent $\mathrm{V}$-notch, and a subsequent row of miniature bosses before breakage prevents further decorative analyses".

Such finds are traditionally dated to the VIII or VII centuries BC. However, in Molloy's opinion based on a comparative analysis with possible analogues, this shield was made in the last centuries of the Bronze Age. He argues that "Bronze Age shields were items of display that either remained visible or were rediscovered in the Iron Age", and, along with offensive weapons, "some served as models for copies designed for display and votive deposition" [12, p. 279]. As the researcher emphasizes, "from Delphi, we therefore appear to have at least two spearheads and one shield (Delphi Shield 1) that have close stylistic parallels and identical technologies to the European $13^{\text {th }}$ - to $11^{\text {th }}$-century series, and a spear-head, two spearheads or swords, and a shield (Delphi Shield 2) that adopt stylized features of Bronze Age objects" [12, p. 297). Thus, the characteristic features of Late Bronze Age weapons were in demand by the Greeks in VIII-VII centuries BC for aesthetic or also for political (legitimation) and religious reasons. This exactly, in our opinion, 
is reflected in Homeric poems, an example of which may be the description and mixing of the shield types in the

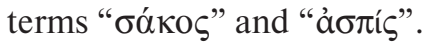

Bershadsky has also analyzed mentioning the shields by Hesiod [2, p. 21] and found that of all the works of Hesiod's corpus, shields are found only in the Shield. There

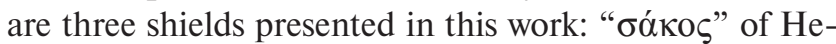

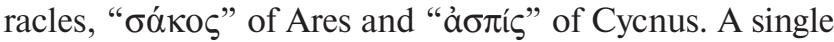
combat between Heracles armed with " $\sigma \alpha ́$ Ko $\varsigma$ " and Cycnus armed with "ảoríc", in the researcher's opinion, is in perfect agreement with similar descriptions from the Iliad:

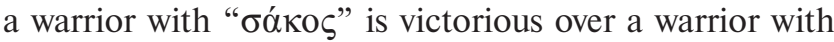

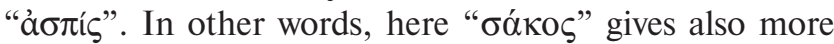
protection. Nevertheless, a slightly different picture is beginning to emerge in the descriptions of the fight between Heracles and Ares, where the winner is Heracles, who twice wounded Ares, which is explained by the author's conception and the expression of Heracles' invincibility.

Researchers note that it is impossible to identify the ty-

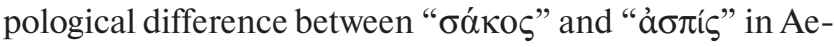
schylus' tragedy Seven Against Thebes, since both shields are qualified as "round" (for example: Sept. 489 - ảo $\pi \dot{\delta} \delta$ o $\varsigma$

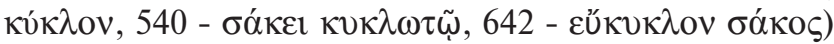
$[22$, p. 259 , n. $6 ; 3$, p. 124 , n. 356]. However, the main emphasis in Aeschylus' description of shields is placed on the symbolism that the shield bears - on what is depicted on it, including what pedagogical aspect this image has [19].

Whenever the so-called "Hoplite revolution" has occurred (and whether the use of such a name is legitimate: see various points of view in [8]), by the time of Aeschylus, the shield of a heavily armed warrior was a hoplite shield. De Groote [4, p. 199] has summarized information about hoplite shields taking into consideration the historiography as follows:

Average diameter, $\mathrm{cm}$............................................ c. 90

Average width of rim, $\mathrm{cm}$.................................... $4.5-5.5$

Average bowl depth, $\mathrm{cm}$..................................... $>10$

Average bowl thickness, $\mathrm{cm}$.................................. . $0.6-2$

Estimated average weight (wooden faced), $\mathrm{kg}$.............. $5-7$

Estimated average weight (with bronze facing), kg ...c.7-9.

Attention is drawn to the detail that permits to effectively use this shield in a close formation - phalanx: "It was equipped with an innovative double-grip system consisting of a central looped arm-band, the porpax, through which the left forearm was slipped as far as the elbow, and a peripheral handle, the antilabe, which was gripped by the hand" [4, p. 198]. Here De Groote also notes that "the offset rim, which averaged between 4.5 and $5.5 \mathrm{~cm}$ in width and $1 \mathrm{~cm}$ in thickness, apparently was always reinforced by a thin layer of bronze, as opposed to the domed outer face of the shield, which could be either left wooden-faced or covered in its entirety by a thin $(\mathrm{c} .0 .05 \mathrm{~cm})$ layer of bronze".

In the writings of Herodotus and Thucydides, the word

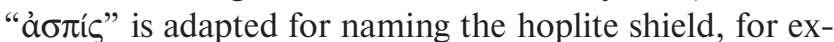
ample: Hdt. 9.74.2 - the shield of the Athenian Sophanes in the Battle of Plataea; Hdt. 8.27.4 - Phocians captured four thousand of Thessalians shields and donated them to Delphi and Abae; Thuc. 3.22.3 - shields of Plataeans; Thuc. 4.9 (corrected for mentioning here a light shield,

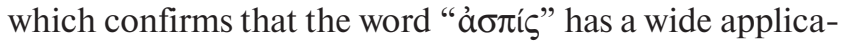
tion [19, p. 125, n. 12]) and 6.58.2 - shields of Athenians; Thuc. 4.12 и 4.38 .1 - shields of Lacedaemonians; Thuc. 4.96.2 - shields of Boeotians [Cf. 3, p. 122-123, n. 336]. Cases of designation of the hoplite shield by the word "ö $\pi \lambda o v$ " are deciphered by Lazenby and Whitehead and probably do not appear earlier than IV century BC [9].

It is intriguing that along with the use of the word "ảoríc" [20, p. 49-50], Herodotus has also used other words designating different types of shields: $\gamma \varepsilon \dot{\varepsilon} \rho \rho-$ Persian shields (Hdt. 7.61.1); $\pi \rho 0 \beta \lambda \eta \dot{\mu} \mu \alpha \alpha$ - shields of Asiatic Ethiopians (Hdt. 7.70.2); $\pi \dot{\varepsilon} \lambda \tau \alpha l$ - the Thracian shileds (Hdt. 7.75.1); and shields of the Cilicians $-\lambda \alpha \imath \sigma \eta \dot{t \alpha}$ (Hdt. 7.91.1) [3, p. 122, n. 331]. Hence, Herodotus definitely evinces the knowledge of the shield types. Against this background it looks like a complete mystery the only

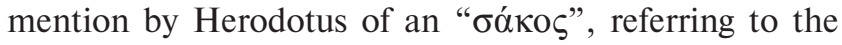
shield that was located in Thebes.

\section{Gifts of Croesus and " $\sigma \alpha ́$ Ko $\varsigma$ " in Thebes}

According to Herodotus (Hdt. 1.92.1; 1.52), the Lydian king Croesus has donated two golden shields and a golden spear to the Greek sanctuaries. One of the shields

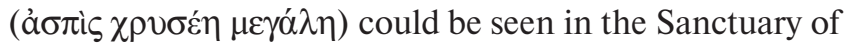

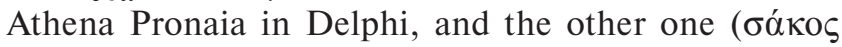

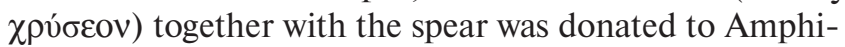
araus in Thebes, but in the time of Herodotus they could be seen in the temple of Apollo Ismenios. In one of our articles, having collecting literary evidences, archaeological and topographical data, we have assumed that "the gifts of Croesus were transported from the Amphiareum to a safer place, i.e. the temple of Apollo Ismenios which was protected by the late Archaic wall of Greater Thebes that included the southeastern sector near Kadmeia" and "the reason was arguably the disturbance caused by the Persian invasion of Greece" [13, p. 78]. In other works, it was analyzed where the sanctuary of Amphiaraus in Thebes could be located and the literary traditions associated with it were established $[21 ; 15]$.

Having mentioned why, from Herodotus' report, " $\sigma \alpha ́ k o \zeta "$, which was considered as a gift of Croesus to Amphiaraus, has been found in the temple of Apollo Ismenios, let us turn to the interpretation of this shield. Buxton believes that since Herodotus so thoroughly distinguish terminologically between the different types of

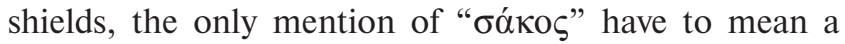
shield that differs from the round "à $\sigma \pi i \varsigma$ ". According to

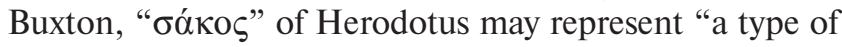
shield no longer in use - a shield which could be associated in Greeks' minds to an heroic past - such as one of the body-shields of LH I, represented in a dagger blade found in grave IV at Mycenae" [3, p. 125]. We agree with Buxton that Herodotus denotes the shield, that probably belongs to another epoch, different from the contemporary with the Herodotus' "ảo $\pi i \varsigma$ ". However, recent discoveries call 
into question the hypothesis that it can be a "tower" type or a "figure-of-eight" shield of Mycenaean time. Firstly, the above-mentioned re-dating of the shield from Delphi shows that the small round shield is also suitable for in-

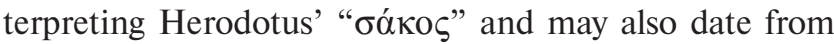
the Late Bronze Age. Let us note one more similarity. In Delphi, in addition to this shield, there has been found two spearheads that, in Molloy's opinion, belong to the Late Bronze Age. Hence, the combination of the round shield and the spear presented by Croesus to Amphiaraus from the story of Herodotus gets an archaeological parallel. If Thebes did not possessed Late Bronze Age artifacts, then it is very likely that similar items (stylistically based on Late Bronze Age artifacts) could later have been made using gold. Moreover, as we have already shown, close in time to Herodotus, Aeschylus in the Seven Against Thebes

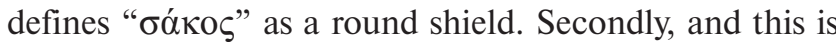
a key point, Papazarkadas has published the inscription, found in Thebes in 2005 [17, pp. 233-248]. According to Papazarkadas, the inscription on the side of the artifact, which is written in the epichoric script of Boiotia, can be dated to the end of VI - beginning of V centuries BC. The researcher believes that the inscription refers to the same artifact that Herodotus saw in the temple of Apollo Ismenios. The inscription tells of an unknown "supervisor" of the sanctuary of Apollo who miraculously discovered the stolen shield of Croesus. However, the inscription

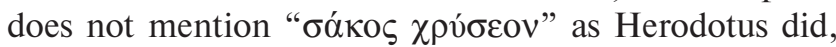

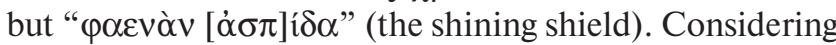
that, as we have established, by the time of Aeschylus and Herodotus, "ả $\sigma \pi i \varsigma^{\prime}$ " is a round shield in the literature, this

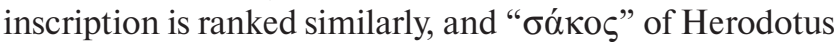
could hardly be shield of a different shape. Perhaps the author of the inscription found in Thebes used the Homeric formula to emphasize the heroic character of this shield,

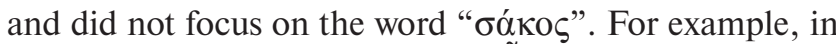

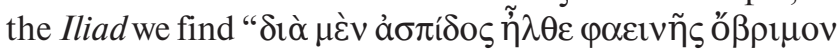

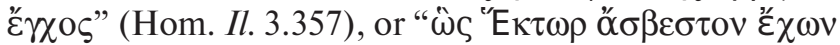

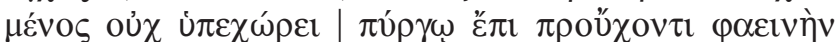

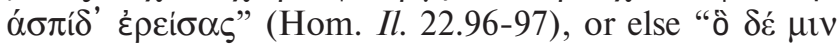

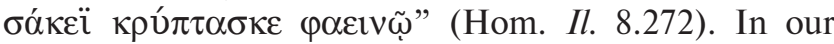
opinion, the key characteristic of the Theban "бóкоৎ" of Herodotus should have been its antiquity and symbolic aspect: heroic and religious. According to Herodotus, this shield was made of gold. For this reason alone, it must have been uncommon. This shield corresponds to the shield owner protectability established by Bershadsky, since Amphiaraus, as a matter of convention, was swallowed up by the earth, saving himself from pursuit. Thus, the hero found himself in some intermediate state between the living and the dead. By convention, reflected in The Mythological Library by Pseudo-Apollodorus, prior to a Periclymenus' chance to strike Amphiaraus in the back, Zeus cleft the earth by throwing a thunderbolt, and Amphiaraus has disappeared along with his chariot and charioteer (Ps.-Apollod. Bibl. 3.6.8). It is possible that Herodo-

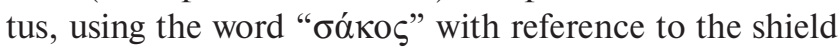

sent to Amphiaraus as a gift, emphasized this aspect too along with antiquity.

\section{Conclusions}

Current state of knowledge regarding literary sources, archaeological, epigraphic and topographical data make it possible to establish that round Greek hoplite shield was called "ả $\sigma \pi i \varsigma$ " by V century BC. Nevertheless, a number of shields being rooted in the Late Bronze Age or made later (in the Geometric or Archaic Period) under the influence of Late Bronze Age artifacts, could be displayed in sanctuaries. Archaeological data evidence that these may have been round-shaped shields, imitating those of the last centuries of the Bronze age. This thesis is confirmed by artifacts from Delphi and some other places. It explains the presence in literary sources, starting with Homeric po-

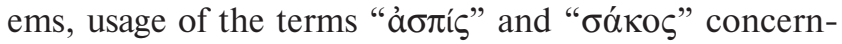
ing heroic shields, which are defined at times as round and at other times as body-shields (images of the latter were found by the Greeks of Archaic times). Herodotus, describing the gifts of Croesus in Thebes, uses the words " $\sigma \alpha ́$ ко $\varsigma$ ", thereby emphasizing the uniqueness of the golden shield, its heroic antiquity and the divine nature - the reliability of the Amphiaraus' shield. This shield, if we take into account the archaeological parallels and the " $\varphi \alpha \varepsilon v \alpha \grave{v} v$ $[\alpha \dot{\sigma} \sigma \pi]\{\delta$ " from an inscription found in Thebes, was probably also circular one.

In summary, we note another constituent of shield in Thebes. In our recent article, by the example of bronze tripods with the Cadmean letters, which Herodotus have seen in the same temple of Apollo Ismenios (Hdt. 5.5761 ), we have noted that the non-ferrous metal artifact could serve "as mediator of relations between a man and the past, the local and national history; it has an influence upon self-determination, self-awareness and education" [14, p. 47]. The artifacts discussed in this paper have also served the same educational purpose. "Golden" or "shining" shield, as well as a spear in the sanctuary of Amphiaraus, and then in the temple of Apollo Ismenios, were the articles that bound up the Thebans with their heroic past, the legendary story of the Seven Against Thebes. Thonemann believes that these gifts were not the gifts of Croesus to Thebes, but were donated to Thebes by an Athenian aristocrat from the Alcmaeonid family [24]. For the context in which we examine the gifts, such a view doesn't change much. And in the article already mentioned above, we have stressed that "recently found inscription proves that Herodotus had indeed visited the Theban Ismenion and had seen the gifts of Croesus, or at least the gifts thought by the Thebans to have been offered by Croesus" $(13$, p. 74). However, if Thonemann turns out to be right, then there is present a change or addition to the educational narrative, influenced by large-scale historical events reflected in the mirror of metal artifacts.

This work is supported by the Russian Science Foundation under grant No. 18-78-10001. 


\section{References}

1. Anderson A. S. The Seven Against Thebes at Eleusis. Illinois Classical Studies. Vol. 40, No. 2. 2015. pp. 297-318.

2. Bershadsky N. The Unbreakable Shield: Thematics of Sakos and Aspis. Classical Philology. Vol. 105, No. 1. 2010. pp. 1-24.

3. Buxton A. H. Lydian Royal Dedications in Greek Sanctuaries. PhD Dissertation. Berkeley, 2002. 247 p.

4. De Groote K. R. 'Twas when My Shield Turned Traitor'! Establishing the Combat Effectiveness of the Greek Hoplite Shield. Oxford Journal of Archaeology. Vol. 35, Iss. 2. 2016. pp. 197-212.

5. Drews R. The End of the Bronze Age. Princeton, 1993. $252 \mathrm{p}$.

6. Grethlein J. Das Geschichtsbild der "Ilias". Göttingen, 2006. $381 \mathrm{p}$.

7. Janko R. The "Iliad": A Commentary. Vol. 4, Books 13-16. Cambridge, $1992.459 \mathrm{p}$.

8. Kagan D., Viggiano G. F. Men of Bronze: Hoplite Warfare in Ancient Greece. Princeton; Oxford, 2013. 286 p.

9. Lazenby J. F., Whitehead D. The Myth of the Hoplite's Hoplon. The Classical Quarterly. Vol. 46, No. 1. 1996. pp. 27-33.

10. Mills S. Theseus, Tragedy and the Athenian Empire. Oxford, 1997. $293 \mathrm{p}$.

11. Molloy B. Nought May Endure but Mutability: Eclectic Encounters and Material Change in the $13^{\text {th }}$ to $11^{\text {th }}$ Centuries b.c. Aegean. In: B. P. C. Molloy (ed.), Of Odysseys and Oddities: Scales and Modes of Interaction between Pre-historic Aegean Societies and Their Neighbours (Sheffield Studies in Aegean Archaeology 10). Oxford, 2016. pp. 343-384.

12. Molloy B. European Bronze Age Symbols in Prehistoric Greece? Reconsidering Bronze Shields and Spears from Delphi in Their Wider Context. Hesperia. Vol. 87, No 2. 2018. pp. 279-309.

13. Mozhajsky A. Yu. The Archaic Wall of Greater Thebes: Chronological and Topographical Problems. Graeco-Latina Brunensia. Vol. 19. Iss. 2. 2014. pp. 71-79.
14. Mozhajsky A. Yu. Bronze in Aegean of the Late Bronze Age: Significance of Metallurgy, Delivering and Consumption. Non-ferrous Metals. No. 1. 2018. pp. 43-48. DOI: 10.17580/ nfm.2018.01.08

15. Mozhajsky A. Yu. The myth of the War of the Seven and Pausanias' educational topography. HYPOTHEKAI. Iss. 4. 2020. pp. 171-206.

16. Osborne R. Greece in the Making, 1200 - 479 BC. London and New York, 2009. $377 \mathrm{p}$.

17. Papazarkadas N. Two New Epigrams from Thebes. In: N. Papazarkadas (ed.), The Epigraphy and History of Boeotia: New Finds, New Prospects. Leiden and Boston, 2014. pp. 223251.

18. Parker V. Untersuchungen zum Lelantischen Krieg und verwandten Problemen der frühgriechischen Geschichte. (Historia Einzelschriften 109.). Stuttgart, 1997. 189 p.

19. Pichugina V. K. The shield as pedagogical tool in Aeschylus' Seven Against Thebes. HYPOTHEKAI. Iss. 4. 2020. pp. 121-170.

20. Powell J. E. A Lexicon to Herodotus. Cambridge, 1938. $392 \mathrm{p}$.

21. Renberg G. H. Where Dreams May Come. Incubation Sanctuaries in the Greco-Roman World. In two volumes. (Religions in the Greco-Roman World 184.). Leiden and Boston, 2017. $1046 \mathrm{p}$.

22. Snodgrass A. M. Early Greek Armour and Weapons. Edinburgh, 1964. $280 \mathrm{p}$.

23. Snodgrass A. M. Arms and Armour of the Greeks. Ithaca, N.Y, 1967. $151 \mathrm{p}$.

24. Thonemann P. Croesus and the Oracles. The Journal of Hellenic Studies. Vol. 136. 2016. pp. 152-167.

25. Vermeule E., Karageorghis V. Mycenaean Pictorial Vase Painting. Cambridge, $1982.417 \mathrm{p}$.

26. West M. L. The Date of the "Iliad". Museum Helveticum. Vol. 52, No. 4. 1995. pp. 203-219.

27. Zimmermann C. Der Antigone-Mythos in der antiken Literatur und Kunst. Tübingen, 1993. 379 p. 